\title{
Techniques for Arbuscular Mycorrhiza Inoculum Reduction
}

Isabel Brito $^{\mathrm{a} *}$, Mário de Carvalho ${ }^{\mathrm{a}}$, Michael J. Goss ${ }^{\mathrm{b}}$

a - Universidade de Évora, ICAM, Apartado 94, 7002 - 554 Évora, Portugal

b - Kemptville College, University of Guelph, Kemptville, Ontario K0G 1J0, Canada

* - Corresponding author: Tel - + 351266760 800, Fax - + 351266760 914, E-mail address: ibrito@uevora.pt

\section{Introduction}

It is well established that arbuscular mycorrhizal (AM) fungi can play a significant role in sustainable crop production and environmental conservation. With the increasing awareness of the ecological significance of mycorrhizas and their diversity, research needs to be directed away from simple records of their occurrence or casual speculation of their function (Smith and Read 1997). Rather, the need is for empirical studies and investigations of the quantitative aspects of the distribution of different types and their contribution to the function of ecosystems.

There is no such thing as a fungal effect or a plant effect, but there is an interaction between both symbionts. This results from the AM fungi and plant community size and structure, soil and climatic conditions, and the interplay between all these factors (Kahiluoto et al. 2000). Consequently, it is readily understood that it is the problems associated with methodology that limit our understanding of the functioning and effects of AM fungi within field communities.

Given the ubiquous presence of AM fungi, a major constraint to the evaluation of the activity of AM colonisation has been the need to account for the indigenous soil native inoculum. This has to be controlled (i.e. reduced or eliminated) if we are to obtain a true control treatment for analysis of arbuscular mycorrhizas in natural substrates. There are various procedures possible for achieving such an objective, and the purpose of this chapter is to provide details of a number of techniques and present some evaluation of their advantages and disadvantages.

Although there have been a large number of experiments to investigated the effectiveness of different sterilization procedures for reducing pathogenic soil fungi, little information is available on their impact on beneficial organisms such as AM fungi. Furthermore, some of the techniques have been shown to affect physical and chemical soil characteristics as well as eliminate soil microorganisms that can interfere with the 
development of mycorrhizas, and this creates difficulties in the interpretation of results simply in terms of possible mycorrhizal activity.

An important subject is the differentiation of methods that involve sterilization from those focussed on indigenous inoculum reduction. Soil sterilization aims to destroy or eliminate microbial cells while maintaining the existing chemical and physical characteristics of the soil (Wolf and Skipper 1994). Consequently, it is often used for experiments focussed on specific AM fungi, or to establish a negative control in some other types of study. In contrast, the purpose of inoculum reduction techniques is to create a perturbation that will interfere with mycorrhizal formation, although not necessarily eliminating any component group within the inoculum. Such an approach allows the establishment of different degrees of mycorrhizal formation between treatments and the study of relative effects.

Frequently the basic techniques used to achieve complete sterilization or just an inoculum reduction may be similar but the desired outcome is accomplished by adjustments of the dosage or intensity of the treatment. The ultimate choice of methodology for establishing an adequate non-mycorrhizal control depends on the design of the particular experiments, the facilities available and the amount of soil requiring treatment.

\section{Solarization}

Solarization is the process of heating soil by covering the land with clear plastic. It is used mainly for control of weeds and plant diseases in regions receiving high levels of solar radiation. In the appropriate climatic regions, a layer of clear plastic film is generally applied to the soil prior to planting and is left in place for 4 to 6 weeks during the hottest part of the year. Because solarization is a hydrothermal process, its success also depends on appropriate levels of moisture to achieve maximum heat transfer. Schreiner et al. (2001) reported an increase in the average daily soil temperature of 6$10^{\circ} \mathrm{C}$ and a maximum daily temperature between $10-16^{\circ} \mathrm{C}$ at $5-20 \mathrm{~cm}$ depth. Al-Momani et al. (1988) reported that solarization lead to the complete elimination of endomycorrhizal fungi at 10 and $20 \mathrm{~cm}$ soil depths, whereas Afek et al. (1991) reported mycorrhizal colonization of cotton roots still occurred after soil solarization.

Bendavid-Val et al. (1997) recognized the uncertainty around whether AM fungi can or cannot survive solarization treatments and developed an extensive study on the subject. Field experiments were carried out in a loamy sand and a silt soil. In both cases the 
presence of indigenous AM fungal populations was investigated using the most probable number (MPN) method. Indigenous fungal populations were reduced to zero after 2 or 4 weeks of solarization treatments, however the Glomus intraradices introduced into the field was not affected, likely due to its tolerance of changing environmental conditions. The dramatic reduction in the number of infective propagules of sensitive species was found to be more pronounced in the upper soil layers then in lower ones. In both experiments, plants (wheat, onion and carrot) sown on solarized plots were colonized within 5 or 6 weeks after emergence. The authors suggested that some of the AM inoculum potential in the soil was in the form of hyphae and was thus particularily sensitive to the high temperatures developed during the solarization treatments and a longer time was required for the few remaining propagules (many as spores) to colonise plant roots. They also concluded that the effect of solarization varied according to AM fungal species, inoculum form, density and host crop together with the duration of solarization.

Schreiner et al. (2001) monitored the infectivity of AM fungi before and after solarization of two fields using a greenhouse bioassay with Sorghum bicolour. Infectivity was greatly reduced in solarized plots 8 months after solarization (over winter) in both years tested. Results were similar for greenhouse or in-field bioassays. These authors concluded that solarization indirectly reduced AM fungi in soil by restricting the weed populations that maintained infective propagules over winter. As with other forms of soil heating, solarization results in complex changes in soil physical, chemical and biological properties. Availability of many mineral nutrients is increased following solarization, particularly those mainly associated with organic matter, such as $\mathrm{NH}_{4}{ }^{+}$and $\mathrm{NO}_{3}{ }^{-}$. Amounts of these ions can vary considerably depending on the aeration of the soil, which is a function of the soil physical properties and moisture content, as well as the presence of nitrifying micro-organisms. Extractable P, $\mathrm{K}, \mathrm{Ca}$ and $\mathrm{Mg}$ may be present in greater concentration after solarization (Stapleton 1990), together with $\mathrm{Cu}$, but $\mathrm{Zn}$ may decrease (Baptista et al. 2006).

The increase in soluble mineral nutrients and the various different effects on AM colonization according to AM fungal species and soil conditions combine to make solarization a tool that needs very careful consideration before use in mycorrhizal research. When AM fungi are re-inoculated after solarization, colonization rates can be 20\% higher (Afek et al.1991; Nair et al. 1990). 


\section{Steam Sterilization}

Autoclaving is widely used to sterilise soil samples, as the equipment is readily available in most microbiology research and teaching laboratories. Soil is autoclaved at $121^{\circ} \mathrm{C}$ at $1.1 \mathrm{~atm}$ for a minimum of $20-30$ minutes. The length of time has to be increased when large amounts of soil are used, but treatment of big volumes at one time should be avoided, and the soil separated into several smaller volume containers to establish an effective distribution of the heat. For the same reasons the soil should not be packed or compressed onto containers, but left unconsolidated to allow the steam to permeate. Cotton material bags perfectly satisfy this requirement. Soil should be airdried or with a water content of less than about $60 \%$ of moisture holding capacity to permit better sterilization (Trevors 1996). Sterilization results in the destruction of both microbial cells and spores. However some resistant spores may germinate after a first cycle of sterilization, so that a second cycle might be recommended after a $24 \mathrm{~h}$ interval. Steam sterilization is an efficient method of eliminating the indigenous population of AM fungi (Smith and Smith 1981; Thompson 1990; Vosátka 1995), however the process may alter the structure and physicochemical properties of the soil (Gantotti and Rangaswami 1971). The effects on the chemical and mineralogical properties, although seemingly not that obvious (Egli et al. 2006), can result in the release of nutrients, which may affect the growth of non-mycorrhizal control plants. Furthermore if there is a re-inoculation with mycorrhizal propagules the elevated nutrient content may hamper root infection by mycorrhizal fungi (Blank et al. 2005).

Net mineralization $\left(\mathrm{NH}_{4}{ }^{+}\right)$levels increase but nitrification is inhibited because of the elimination of nitrifying bacteria, as a result of steam sterilization. There is also an enhancement of the extractable $\mathrm{P}$ content and can be a slight increase in $\mathrm{pH}$ (Thompson 1990; Alphei and Scheu 1993). Depending on the soil, release of trace elements such as $\mathrm{Mn}, \mathrm{Fe}$ and $\mathrm{Cu}$ is also promoted by steam sterilization (Arybod et al. 2006).

The changes resulting from steam sterilization has limited its adoption as a technique for establishing negative AM control. However Smith and Smith (1981) studied the effect of early endomycorrhizal infection on nodulation and growth of Trifolium subterraneum L. in non-sterilized and steam sterilized soil. They concluded that growth differences were a classical mycorrhizal response and did not reflect toxic effects of sterilization. Significantly, Smith and Smith (1981) reported that the growth of Brassica oleracea (broccoli), which does not form mycorrhiza, was better on sterilized soil. 


\section{Pasteurization}

The pasteurization process involves the application of heat, but raises the temperature of the soil for shorter periods of time than required for steam sterilization. Consequently, chemical changes in the soil are also not as great.

Heating the soil to $60^{\circ} \mathrm{C}$ for $4 \mathrm{~h}$, had no significant affect on soil nutrient concentrations and reduced AM colonization of Plantago lanceolata roots by less than 1\% (Endlweber and Scheu 2006) suggesting that moderate heating is preferable to other methods, at least for experiments to investigate effects of arbuscular mycorrhza and their interactions with decomposer organisms on plant growth.

The only differences found between the nutrients of pasteurized (soil slowly heated to $80^{\circ} \mathrm{C}$, maintained at this temperature for $2 \mathrm{~h}$, and then allowed to cool) and nonpasteurized soils were increased extractable $\mathrm{NH}_{4}{ }^{+}-\mathrm{N}$ and $\mathrm{NO}_{3}{ }^{-}-\mathrm{N}$ (McGonigle and Miller 1996). There were no changes to concentration of $\mathrm{P}, \mathrm{Mg}$ or $\mathrm{K}$ nor to $\mathrm{pH}$, but arbuscules in roots were reduced to trace numbers. Scagel (2004) reported only trace AM colonization of Brodiaea "Queen Fabiola" in pasteurized soil.

\section{Gamma ( $(\mathrm{-})$ ) Irradiation}

A number of studies have suggested that $\gamma$ - irradiation is highly effective as a biocide and preferable to other methods of treating soil, because it can have less of an impact on soil chemical and physical properties, including little effect on particle size or aggregate stability (Bowen and Rovira 1961; McLaren 1969). The advantage of $\gamma$-radiation over other similar techniques is that it does not induce sample radioactivity making handling safe, on the other hand it requires special equipment not readily available in most laboratories.

Generally the greater the size or complexity of an organism the more susceptible to radiation it is, fungi seem to be more sensitive then bacteria (McLaren 1969). The larger the sample the more likely that a variable dose may be delivered due to internal shielding from irradiation (Yardin et al. 2000). An irradiation source strength of $3 \mathrm{kGy}$, smaller than the $10 \mathrm{kGy}$ usually recommended, may be enough to eliminate AM fungi infectivity and have little impact on soil conditions (Kahiluoto 2000; Thompson 1990). However, radiation requirements depend upon the soil type, moisture content and former management (Powlson and Jenkinson 1976; Parekh et al. 2005). As a consequence of soil $\gamma$-irradiation short-term increases in temperature and nutrient

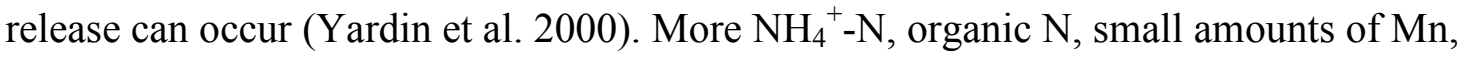


soluble $\mathrm{C}$ and exchangeable $\mathrm{S}$ and $\mathrm{P}$ have been reported after $\gamma$-irradiation of soil (Alphei and Scheu 1993; McLaren 1969, Thompson 1990). $\mathrm{NO}_{3}{ }^{-}-\mathrm{N}$, generally declines after $\gamma$-irradiation but $\mathrm{pH}$ variation showed no consistent trends (McNamara et al. 2003). The release of soil bound residues is not modified by $\gamma$-irradiation compared with autoclaving (Nakagawa and Andrea 1997).

One of the clear advantages of $\gamma$-irradiation is that it is highly effective at sterilization and leaves no chemicals contamination post-treatment and re-inoculation experiments can take advantage of this. Of particular interest is the potential for $\gamma$-irradiation to be used as a tool for selectively manipulating biodiversity in soils while causing minimal disruption (McNamara et al. 2003). Comparing AM inoculated and non-inoculated plants in partially sterilized soil at $10 \mathrm{kGy} \gamma$-irradiation, Thompson (1990) unreservedly recommended the method for use in nutritional studies.

\section{Chemicals}

Various gaseous chemicals (ethylene oxide, propylene oxide, chloroforms) have been used to fumigate soil. Methyl bromide $\left(\mathrm{CH}_{3} \mathrm{Br}\right)$, an extremely poisonous gas, appears to be especially toxic to AM fungi and many researchers have used it fumigant to eradicate AM fungi from experimental soils (Plenchette et al. 1983; Thompson 1990; Vosátka 1995), however toxic effects of inorganic bromide residues in the soil and phytoxicity symptoms resulting from $\mathrm{Br}$ concentrations in plant tissue may occur (Alphei and Scheu 1993; Thompson 1990). Use of methyl bromide is being banned due to its adverse effect on the ozone layer and is scheduled to be phased out in the second decade of the new century (Bell 2000).

Ethylene oxide $\left(\mathrm{C}_{2} \mathrm{H}_{4} \mathrm{O}\right)$ is a colourless, flammable gas at room temperature and pressure. To sterilize soil, it is introduced under reduced pressure to containers holding the soil in pots or trays. Changes in the soil physical and chemical properties seem to be minor (Rose and Bailey 1952).

Propylene oxide $\left(\mathrm{C}_{3} \mathrm{H}_{6} \mathrm{O}\right)$ is a colourless, extremely flammable liquid that can alkylate functional groups of proteins. In a comparison of propylene-oxide treated soil with untreated material, Alphei and Scheu (1993) reported a marked increase in the $\mathrm{CO}_{2}$ release throughout the experiment and a smaller mineral nitrogen content, indicating immobilization of $\mathrm{N}$ for microbial growth.

Both ethylene and propylene oxide can increase soil $\mathrm{pH}$ during fumigation and produce residues that hinder plant growth (Trevors 1996). 
Chloroform $\left(\mathrm{CHCl}_{3}\right)$ is highly volatile and has been used to fumigate soils for the estimation of microbial biomass. Chloroform fumigation can defaunate the soil, not necessarily eliminating microbial populations completely (Alphei and Scheu 1993). Endlweber and Scheu, (2006) reported a massive reduction in AM colonization of Plantago lanceolata roots by more than $99 \%$ in plants from chloroform treated soil, but there was also an effect on plant growth and nutrient concentrations within plant tissue . Other fungicidal chemicals, can also be used to prevent the development of arbuscular mycorrhiza. Mostly these chemicals adversely affect AM fungi (Manjunath and Bagyaraj 1984; Salem et al. 2003) although the degree of toxicity varies with the active ingredient, the application rate (Habte and Manjunath 1992) and specific AM fungal isolate (Schreiner and Bethlenfalvay 1997). The disadvantages of using fungicides to create an indigenous-inoculum-freesoil relate to the fungicide residues left in the soil that might be toxic to reinoculated microbes or to the plants. According to Kahiluoto et al. (2000) Benomyl (carbendazin) incorporation in the soil besides being most effective in supressing AM fungi is the most apropriate method currentely available to create a non-mycorrhizal control for AM fungi community in the field, irrespective of soil type and management history since Benomyl treatment showed no ecologically significant effects on soil $\mathrm{pH}$ or $\mathrm{K}, \mathrm{Ca}$ and $\mathrm{Mg}$ contents or phytotoxicity agents like $\mathrm{Al}, \mathrm{Fe}, \mathrm{Cu}$ or $\mathrm{Mn}$, in the experiments they performed.

The use of formaldehyde to supress AM fungi was tested by Covacevich and Echeverria (2003) and they concluded that the concentration range of 1,67 to 5\% (formaldehydewater) effectively eliminated indigenous mycorrhizal colonization without restricting plant growth and allowed the development of inoculated AM isolates.

An extensive review made by Menge (1982), on the effects of many other fumigants and fungicides specifically on AM fungi, is highly recommended despite the passage of time since it was published.

\section{Soil disturbance}

The direct effects of soil disturbance on mycorrhization are related to physical disruption of the soil hyphal network and to the mixing of surface residues within the soil profile, affecting the effectiveness of AM symbiosis.

When host plants are present and the soil is not disturbed, hyphae from colonized roots and mycelia network are the main source of inoculum, they are more rapid and efficient at initiating colonization (Martins and Read 1997) than are spores. Spores are 
considered to be "long-term" propagules (Kabir 2005), mainly because it would take longer for spores to germinate and for the hypha to make contact with roots as opposed to runner hyphae infection from well developed extraradical mycelium (Klironomos and Hart 2002). Evans and Miller (1990) demonstrated that disruption of the hyphal network was directly responsible for much of the effect of soil disturbance on mycorrhizal colonization, leading to differences in AM colonization of almost $50 \%$ in pot trials and Brito et al. (2006), under field conditions, reported 20\% differences in AM colonization of wheat.

Besides, deep ploughing (to more than $15 \mathrm{~cm}$ ) hinders subsequent mycorrhiza formation by reducing propagules density in the rooting zone (Kabir et al. 1998). Abbott and Robson (1991) observed that no-tilled soil had more spores in the top $8 \mathrm{~cm}$ whereas tilled soils had more spores in the $8-15 \mathrm{~cm}$ depth.

Fairchild and Miller (1988) developed a "Cycles Technique" to study the differences in AM colonization and $\mathrm{P}$ absorption in disturbed and undisturbed soil. Air dried soil was sieved ( 5 or $4 \mathrm{~mm}$ ), packed into the pots to a natural bulk density of approximate 1,2 $\mathrm{g} / \mathrm{cm}^{3}$ and sown with the desired plant. Three weeks after emergence, plant shoots were excised and measured. Half of the pots were then taken, the soil removed as two layers and passed separately through a $4 \mathrm{~mm}$ sieve. All root material separated on the sieve was cut into $2 \mathrm{~cm}$ long segments and mixed into the soil of the appropriate layer. Soil was repacked in the pots and arranged in the same two layers. In the other half pots the soil remained undisturbed. The pots were reseeded and a new cycle initiated. The authors argued that the possible microbial flush of $\mathrm{N}$ (mineralization) in the soil caused by disturbance ought to be negligible compared with the relatively large concentrations of $\mathrm{N}(100 \mu \mathrm{g} / \mathrm{g})$ added to the soil at the start of the experiment and further insist, this small amount of $\mathrm{N}$ will mainly be released in the initial phase of the experiment. The effect of soil disturbance on AM infection could be mediated through changes in soil physical properties, however bulk density measurements were unable to discern any significant differences between the two soil treatments.

Using this technique, and after 3 or 4 cycles of disturbance, greater colonization rates are observed consistently in plants coming from undisturbed soil pots (Goss and de Varenes 2002; McGonigle et al. 2003; Antunes et al. 2006; Brito et al. 2006). A number of advantages are associated with this technique, namely the fact that it doesn't make use of any toxic compounds, causes little nutrient release, exploits the 
naturally occurring inoculum and allows a common history of inoculum and host plant throughout the successive cycles.

\section{Crop rotation}

Although most crops are dependent upon mycorrhizal fungi, roots of some crops like for example the ones belonging to the Chenopodiaceae and Brassicaceae families do not form mycorrhiza. When such crops are used in rotations, they tend to lead to a reduction in mycorrhizal propagules. Arihara and Karasawa (2000) studied the effects of fallow and the previous cultivation of sunflower, maize, soybean, potato, sugar beet and canola (oilseed rape) on AM colonization of maize and found that shoot weight and grain yield of maize were much greater in the plots following sunflower, maize, soybean and potato than those after canola or sugar beet (non-mycorhizal crops) or fallow. The cultivation of a non-AM host such as sugar beet or canola, reduces the mycorrhizal propagules and consequently AM colonization of the folowing crop (Arihara and Karasawa 2000;

Gollner et al. 2004) even with no alteration to the availability of $\mathrm{P}$ in the soil induced by the previous crop (Karasawa et al. 2001).

Reduction of AM propagules is also associated with the practice of bare-fallow. Because AM fungi are strictly biotrophic, their survival depends on the presence of host plants. Harinikumar and Bagyraj (1988) reported that leaving the land fallow decreased the mycorrhizal propagules in $40 \%$, while growing a non-mycorrhizal host reduced it by $13 \%$.

\section{Other methods}

Ozone, possessing strong oxidative and germicidal properties, has a very short half-life of minutes or less in soil and decomposes to simple diatomic oxygen. Takayama et al. (2006) developed an ozonation technology based on the generation of electrical discharges by applying high voltage to soil placed between two electrodes. Soil treatments of $20 \mathrm{~g} \mathrm{O}_{3} / \mathrm{m}^{3}$ for 10 min almost killed Fusarium oxysporum and with a 20 min treatment over $80 \%$ of the soil bacteria were eliminated.

Although not directly interfering with the AM inoculum the use of isogenic myc ${ }^{-}$ mutants of AM hosts as a non-mycorrhizal control may be useful to avoid disruptive soil treatments and the safety and enviromental problems caused by most of the chemicals. The use of myc ${ }^{-}$mutants was investigated by Kahiluoto et al. (2000), but problems with AM dependence, compatibility with indigenous AM fungi communities 
and agricultural relevance due to the limited selection of myc ${ }^{-}$mutants available are dificult to overcome. AM mutants currently available have all been isolated from preexisting nod ${ }^{-}$pools. As a result these mutants have modified genes genes that play a role in both mycorrhiza formation and nodulation. Given the fact that nodulation is essentially restricted to one plant family, whereas AM are widespread, a significant number of mycorrhiza-specific genes must exist (Marsh and Schultze 2001), once they are identified, myc ${ }^{-}$mutants may became a more helpful tool for non-mycorrhizal controls.

\section{Conclusions}

No method developed for reducing the competition from indigenous AM fungi is ideal for every application, and some still require a full evaluation. Table 1 summarizes the techniques described, their effect on AM inoculum and indicates some of the implications for soil physical (structure) and chemical (nutrient release) characteristics.

\section{Table 1}

Judicious use of crop rotations provides an important opportunity to minimise the competition to introduced inoculum from indigenous AM fungal species on a field scale without having major impacts on the general nutrient status of the soil or on the structure of the soil, weeds and volunteer plants could reduce its efficacy. Furthermore, the time frame for preparing the land requires long-term planning. Most rapid approaches have limitations because of the volume of soil that can be treated at one time, or because of changes in nutrient availability or structural properties. As we improve our ability to characterize species diversity and quantify the number of individuals in real time, techniques that encourage the use of local indigenous beneficial species may be of greatest benefit. 
Table 1 - Techniques for AM inoculum reduction and main implications for soil properties.

\begin{tabular}{|c|c|c|c|c|c|}
\hline \multirow[t]{2}{*}{ Method } & \multicolumn{2}{|c|}{ AM inoculum } & \multicolumn{2}{|c|}{$\begin{array}{c}\text { Soil chemical and physical } \\
\text { effects }\end{array}$} & \multirow[t]{2}{*}{ Comments } \\
\hline & Elimination & Reduction & $\begin{array}{l}\text { Nutrient } \\
\text { release }\end{array}$ & $\begin{array}{c}\text { Soil } \\
\text { Structure }\end{array}$ & \\
\hline Solarization & & $\mathrm{X}$ & Yes & kept & Appropriate climate conditions \\
\hline Steam Sterilization & $\mathrm{X}$ & & Yes & Changed & $\begin{array}{l}\text { Easily available, small volumes } \\
\text { of soil treated at any one time }\end{array}$ \\
\hline Pasteurization & & $\mathrm{X}$ & Only N & Kept & Less destructive then sterilization \\
\hline$\gamma$ Irradiation & $\mathrm{X}$ & & Very few & Kept & $\begin{array}{l}\text { No post-treatment chemicals, } \\
\text { small volumes of soil treated at } \\
\text { any one time }\end{array}$ \\
\hline Chemicals & $\mathrm{X}$ & & Yes & Kept & Toxicity \\
\hline Soil disturbance & & $\mathrm{X}$ & No & Changed & Time consuming \\
\hline Crop rotation & & $\mathrm{X}$ & No & Kept & Time consuming \\
\hline Ozone, myc ${ }^{-}$plants & - & - & - & - & - \\
\hline
\end{tabular}

\section{Reference list}

Abbott LK, Robson AD (1991) Field management of VA mycorrhizal fungi. In: Keister DL, Gregan PB (Eds) The Rhizosphere and Plant Growth. Kluwer Academic Publishers, Netherlands, pp 355-362

Afek U, Menge JA, Johnson ELV (1991) Interaction among mycorrhizzae, soil solarization, metalaxyl, and plants in the field.". Plant Dis 75:665-672

Al-Momani A, Abugarbiah W, Saleh H, 1988 The effect of soil solarization on endomycorrhizal fungi (Gomus mosseae) and Fusarium fungi. Dirasat 15:85:95

Alphei J, Scheu S (1993) Effects of biocidal treatments on biological and nutritional properties of a mullstructured woodland soil. Geoderma 56: 435-448

Antunes PM, Deaville D, Goss MJ (2006) Effect of two AMF life strategies on the tripartite symbiosis with Bradyrhizobium japonicum and soybean. Mycorrhiza 16:167-173

Arihara J, Karasawa T (2000) Effect of previous crops on arbuscular mycorrhizal formation and growth of succeeding maize. Soil Sci Plant Nutr 46:43-51

Aryabod S, Fotovat A, Lakzian A, Haghnia G (2006) The Effect of Soil Sterilization on Zn, Cu, Fe, and Mn Uptake by Maize. Abs 961b, 18th World Congress of Soil Science Philadelphia, Pennsylvania, USA

Baptista MJ, Souza RB, Pereira W, Carijo AO, Vidal MC, Charchar JM (2006) Solarização do solo e biofumigação no cultivo protegido do tomate. Hortic Bras 4:47-52

Bell CH (2000) Fumigation in the 21st century. Crop Protection 19:563-569

Bendavid-Val R, Babinowitch HD, Katan J, Kapulnik Y (1997) Viability of VA-mycorrhizal fungi following soil solarization and fumigation. Plant and Soil 195:185-193

Blanke V, Renker C, Wagner M, Füllner K, Held M, Kuhn AJ, Buscot F (2005) Nitrogen supply affects arbuscular mycorrhizal colonization of Artemisia vulgaris L. in a phosphate- polluted field site. New Phytol 166:981-992

Bowen GD, Rovira AD (1961) Plant Growth in Irradiated Soil. Nature 191:936-937

Brito I, Carvalho M, van Tuinen D, Goss MJ (2006) Effects of soil management on arbuscular mycorrhizal fungi in Autumn-sown crops in Mediterranean climates. In: Soil Management for sustainability, Advances in Geoecology 38. Horn R, Fleige H, Peth S, Peng X, (Eds) Catena Verlag GMBH, Germany, pp149-156

Covacevich F, Echeverria HE (2003) Utilización de formaldehido para la erradicación de hongos micorríticos arbusculares de muestras de suelo. Ciencia del Suelo 21: 9-17

Egli M, Mirabella A, Kägi B, Tomasone G, Clorio G (2006) Influence of steam sterilisation on soil chemical characteristics, trace metals and clay mineralogy. Geoderma 131:123-142 
Endlweber K, Scheu S (2006) Establishing arbuscular mycorrhiza-free soil: A comparison of six methods and their effects on nutrient mobilization. Applied Soil Ecology 34:276-279

Evans DG, Miller MH (1990) The role of the external mycelial network in the effect of soil disturbance upon vesicular-arbuscular mycorrhizal colonization of maize. New Phytol 114:65-71

Fairchild GL, Miller MH (1988) Vesicular-arbuscular mycorrhizas and the soil-disturbance-induced reduction of nutrient absortion in maize. II. Development of the effect. New Phytol 110:75-84

Gantotti BV, Rangaswami G (1971) Improvements in the physical properties of soil under the influence of the rhizosphere microflora of four different plant species . Plant and Soil 35: 347-356

Gollner M, Friedel JK, Freyer B (2004) Influence of different agricultural practices on the arbuscular mycorrhiza in organic farming systems. In: Baar J and Josten E (eds) Applied Plant Research, WUR, Netherlands: Role of mycorrhiza in sustainable land management. COST 8.38 Meeting, 2627.02.2004, Vught, Netherlands

Goss MJ, de Varennes A (2002) Soil disturbance reduces the efficacy of mycorrhizal associations for early soybean growth and N2 fixation. Soil Biol and Biochem 34: 1167-1173

Habte M, Manjunath A (1992) Initial and residual toxicity of soil-applied thiram on the vesiculararbuscular mycorrhizal symbiosis. Mycorrhiza 2:25-31

Harinikumar KM, Bagyaraj DJ (1988) Effect of crop rotation on native vesicular arbuscular mycorrhizal propagules in soil. Plant and Soil 110:77-80

Kabir Z (2005) Tillage or no-tillage: Impact on mycorrhizae. Canadian Journal of Plant Science 85:23-29

Kabir Z, O`Halloran I P, Widden P, Hamel C (1998) Vertical distribution of arbuscular mycorrhizal fungi under corn (Zea mays L.) in no-till and conventional tillage systems. Mycorrhiza 8:53-55

Kahiluoto H, Ketoja E, Vestberg M (2000) Creation of a non-mycorrhizal control for a biossay of AM effectiveness. Mycorrhiza 9:241-258

Karasawa T, Kasahara Y, Takebe M (2001) Variable response of growth and arbuscular mycorrhizal colonization of maize plants to preceding crops in various types of soils. Biol Fertil Soils 33:286293

Klironomos JN, Hart MM (2002) Colonization of roots by arbuscular mycorrhizal fungi using different sources of inoculum. Mycorrhiza 12:181-184

Manjunath A, Bagyaraj DJ (1984) Effects of fungicides on mycorrhizal colonization and growth of onion. Plant and Soil 80:147-150

Marsh JF, Schultze M (2001) Analysis of arbuscular mycorrhizas using symbiosis-defective plant mutants. New Phytol 150:525-532

Martins MA, Read DJ (1997) The effects of disturbance on the external mycelium of arbuscular mycorrhizal fungi on plant growth. Pesqui Agropecu Bras 32:1183-1189

McGonigle TP, Miller MH (1996) Development of fungi below ground in association with plants growing in disturbed and undisturbed soils. Soil Biol and Biochem 28:263-269

McGonigle TP, Yano K, Shinhama T (2003) Mycorrhizal phosphorus enhancement of plants in undisturbed soil differs from phosphorus uptake stimulation by arbuscular mycorrhizae over nonmycorrhizal controls. Biology and Fertility of Soils 37:268-273

McLaren AD (1969) Radiation as a technique in soil biology and biochemistry. Soil Biol and Biochem $1: 63-73$

McNamara NP, Black HIJ, Beresford NA, Parekh NR (2003) Effects of acute gamma irradiation on chemical, physical and biological properties of soils. Appl Soil Ecol 24:117-132

Menge JA (1982) Effect of soil fumigants and fungicides on vesicular-arbuscular fungi. Phytopathology $72: 1125-1132$

Nair SK, Peethambaran CK, Geetha D, Nayar K, Wilson KI (1990) Effect of soil solarization on nodulation, infection by mycorrizal fungi and yield of cowpea. Plant and Soil 125:153-154

Nakagawa LE, Andrea MM (1997) Liberação de resíduos ligados de atrazina de solos por meio de esterilização por autoclavagem e radiação gama. Revista Brasileira de Ciência do Solo 21:707-710

Parekh NR, Potter ED, Poskitt J S, Dodd B A, Beresford NA (2005) Detection of irradiation induced changes on the activity and diversity of soil microbial communities: the effect of soil type. Radioprotection 40:S939-S944

Plenchette C, Fortin JA, Furlan V (1983) Growth response of several plants species to mycorrhiza in a soil of moderate P fertility. I. Mycorrhizal dependency under field conditions. Plant and Soil 70:199-209

Powlson DS, Jenkinson DS (1976) The effects of biocidal treatments on metabolism in soil. II. Gamma irradiation, autoclaving, air-drying and fumigation. Soil Biol and Biochem 8:179-188

Rose RE, Bailey RW (1952) Ethylene oxide for soil sterilisation. Nature 169: 716

Salem SF, Dobolyi C, Helyes L, Pçk Z, Dimçny J (2003) Side-effect of benomyl and captan on arbuscular mycorrhiza formation in tomato. Acta Hort (ISHS) 613:243-246 
Scagel CF (2004) Soil pasteurization and mycorrhizal inoculation alters flower production and corm composition of Brodiaea laxa. 'Queen Fabiola'. Hort Science 39:1432-1437

Schreiner RP, Ivors KL, Pinkerton JN (2001) Soil solarization reduces arbuscular mycorrhizal fungi as a consequence of weed suppression. Mycorrhiza 11:273-277

Schreiner RP, Bethlenfalvay GJ (1997) Mycorrhizae, biocides, and biocontrol. 3. Effects of three different fungicides on developmental stages of three AM fungi. Biol Fertil Soils 24:18-26

Smith SE, Read DJ (1997) Mycorrhizal Symbiosis. Academic Press, London

Smith FA, Smith SE (1981) Mycorrhizal Infection and Growth of Trifolium subterraneum: Use of Sterilized Soil as a Control Treatment. New Phytol 88:299-309

Stapleton JJ (1990) Thermal inactivation of crop pests and pathogens and other soil changes caused by solarization. In: International Conference of Soil Solarization, Ammam. Proceedings. Rome: DAO, 1991. pp 37-47

Takayama M, Ebihara K, Stryczewska H, Ikegami T, GyoutokuY ,Kubo K, Tachibana M (2006) Ozone generation by dielectric barrier discharge for soil sterilization. Thin Solid Films 506-507: 396-399

Thompson JP (1990) Soil sterilization methods to show VA- mycorrhizae aid P and Zn nutrition of wheat in vertisols. Soil Biol and Biochem 22:229-240

Trevors JT (1996) Sterilization and inhibition of microbial activity in soil. J Microbiol Methods 26:53-59

Vosátka M (1995) Influence of inoculation with arbuscular mycorrhizal fungi on the growth and mycorrhizal infection of transplanted onion. Agric Ecosy and Enviro 53: 151-159

Wolf DC, Skipper HD (1994) Soil sterilization. In: Weaver RW, Angle JS, Bottomley PS, Bezdicek D, Smith S, Tabatabai A, Wollum A, Mickelson SH (eds) Methods of Soil Analysis, Part 2Microbiological and Biochemical Properties. Soil Science Society of America Inc. pp 41-51

Yardin MR, Kennedy IR, Thies JE (2000) Development of high quality carrier materials for field delivery of key microorganisms used as bio-fertilisers and bio-pesticides. Radiation Phys Chem 57:565-568 